\title{
Self-portrait in a Convex Mirror: Colonial Italy Reflects on Tianjin
}

\section{Maurizio Marinelli}

\section{(2) OpenEdition}

\section{Journals}

\section{Electronic version}

URL: http://journals.openedition.org/transtexts/147

DOI: $10.4000 /$ transtexts. 147

ISSN: 2105-2549

\section{Publisher}

Gregory B. Lee

\section{Printed version}

Date of publication: 1 September 2007

Number of pages: 119-150

ISSN: 1771-2084

\section{Electronic reference}

Maurizio Marinelli, « Self-portrait in a Convex Mirror: Colonial Italy Reflects on Tianjin », Transtext(e)s

Transcultures 跨文本跨文化 [Online], 3 | 2007, Online since 15 October 2009, connection on 01 May 2019. URL : http://journals.openedition.org/transtexts/147 ; DOI : 10.4000/transtexts. 147 


\section{Self-portrait in a Convex Mirror: Colonial Italy Reflects on Tianjin}

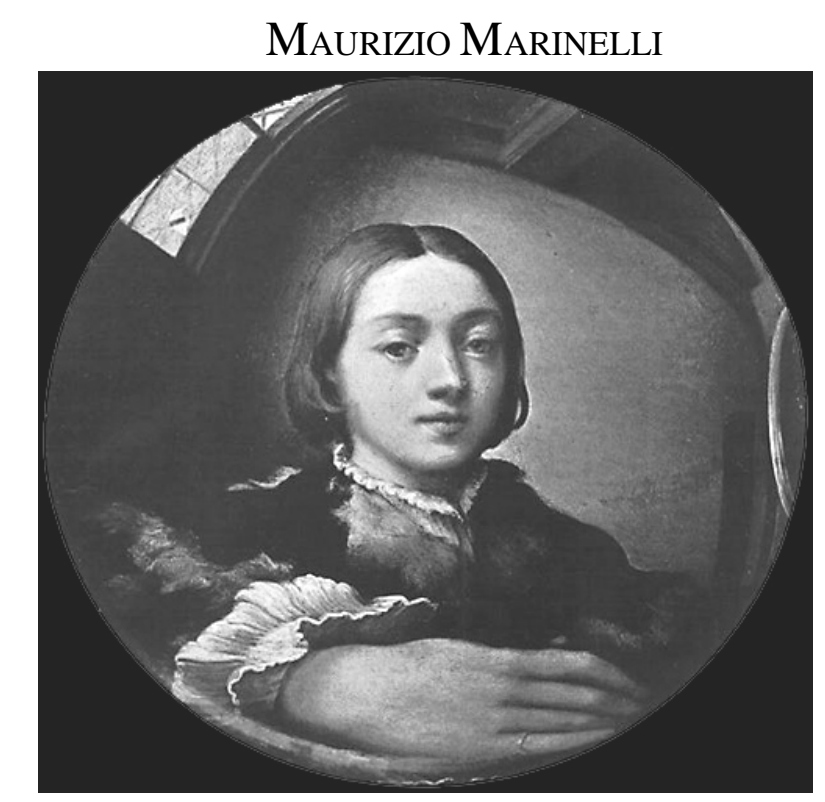

Figure 1. Parmigianino, «Self-Portrait in a Convex Mirror». ${ }^{1}$

This article focuses on the sole Italian concession (zujie) that existed in China between 1901 and 1947. This is the only example of Italian colonialism in Asia. The concession

1 «Self-portrait in a Convex Mirror» is a 16th century painting by Parmigianino and refers to distortion. See: Parmigianino, Self-Portrait. 1524, Kunsthistorisches Museum, Vienna; image courtesy of ArtOnline. http://www.artonline.it/opera.asp?IDOpera=402; retrieved on 20 May 2006. 
was located in the Hebei district of the modern municipality of Tianjin. It was established in 1901 as a consequence of the signature of the "Boxer Protocol», since Italian troops had participated in an international military mission, called the eightnation alliance, which on 14 August 1900 had entered and occupied Beijing, putting an end to the Boxer Rebellion. The article compares the theoretical bases which underpinned the different representations of the Italian concession, as produced by observers, diplomats, and scholars in China and Europe in different time periods. The final objective is to investigate the historical reasons behind the emphasis that was placed on specific socio-economic, institutional, and cultural aspects of the Italian concession. The analysis focuses in particular on the two major themes, which emerge as constant traits from the sources: 1 . The history of the concession, its acquisition, socio-spatial organisation, and ultimately its reorganisation as a «laboratory of modernity»; and 2. The notion of shaping the Italian concession as an Italian-style neighbourhood, a miniature Disneyland-style venue of «Italianness» or «Italian spirit» (e.g. according to the rhetoric trope of «Italianità), constructed especially in terms of spatial re-presentation and cultural superimposition.

\section{Methodology and Objectives}

As an historian, I am particularly interested in the dismantlement of the old traditional view of history as an «unproblematic, extra-textual and extra-discursive real». ${ }^{2}$ My intention is to use the selected written sources in a dialogic way in order to expose the representation of the Italian concession and elucidate the reasons for what I believe, is a deliberate informative and descriptive selectivity, revealing partisan and often prescriptive overtones. I will argue that, the extremely positive master narrative predominant in the Italian sources is informed by socially encoded and constructed discursive practices. These were generated by varying sociopolitical and economic interests, and often motivated by precise speculative transactions that were simply justified by the principle of emulation of well established colonial practices. This is demonstrated for example, by Ambassador Giovanni Gallina's justification of the immediate expropriation of what he referred

2 Catherine Belsey, «Making Histories Now and Then. Shakespeare from Richard II to Henry V» in F.Barker, P. Hulme, and M. Iversen, eds, Uses of History: Marxism, Postmodernism and the Renaissance, Manchester: Manchester University Press, 1991, p.26. 
to as the «filthy Chinese village», arguing that «all the other powers had proceeded to the expropriation as soon as they occupied the area of their concession». ${ }^{3}$

Two interpretive paradigms are particularly useful in the analysis of the Italian concession. The first one is the concept of «re-presentation». The second is the process of construction and deconstruction of «imagined communities». By representation I mean a second or new form of presentation, as expressed for example in the arts. ${ }^{4}$ For the purpose of this work, I am referring to the idea of ideologically motivated re-presentation, which intrinsically embodies a performative nature and responds to a teleological mechanism. ${ }^{5}$

The first problem with the teleological mechanism of historical re-presentation is the creation of a hegemonic relation of power: teleology is reductive, exclusionary and harmful to those whose stories are erased. Secondly, this kind of representation is based on the concept of time as a linear and progressive notion, which excludes any objective analysis of space. The structural transformation over time of the territory identified as the Italian concession is one of the main themes reflected in the sources that I have collected. However, this transformation is often one-sidedly analysed, leading to the apotheosis of an imported idea of modernity. Therefore, I intend to critique a certain model of ideological re-presentation that demonstrates an instrumental devaluation of spatial thinking, in order to justify the appropriation of the indigenous space, the erasure of its identity and the superimposition of the colonial one.

Foucault pointed in the direction of conceptualisation of space as a social process where strategies of power and signification jointly operate. ${ }^{6}$ In the Italian case, the representations produced by colonial narratives and practices have constructed a hagiographic picture of the Italian «civilizing mission», based on the 1890s claim that «Italy's was a «proletarian» colonialism» and therefore less pernicious than the others; since it would have been «aimed to secure better land and greater prosperity

3 Ministero degli Affari Esteri, Direzione Generale degli Affari Commericali. Concessione italiana di Tien Tsin, Pro Memoria, in ASMAE, Serie P, pos. 86/37, pac. 429 (1912-1914).

${ }^{4}$ Georges Didi-Huberman, Confronting Images: Questioning the Ends of a Certain History of Art, University Park: Penn State Press, 2005. Didi-Huberman suggests that art historians should look to Freud's concept of the «dreamwork» to begin to think of representation as a mobile process that often involves substitution and contradiction.

5 According to Lyotard teleology and «grand narratives» are eschewed in a post-modern attitude. JeanFrançois Lyotard, The Postmodern Condition: A Report on Knowledge, Minneapolis: University of Minnesota Press, 1984.

6 Michel Foucault, Power/Knowledge: Selected Interviews \& Other Writings 1972-1977, New York: Pantheon Books, 1980, p.149. 
for its indigenous citizens». ${ }^{7}$ In the last thirty odd years, postcolonial multiple perspectives have overcome colonial elitist views, and discourse analysis, integrated with historical interpretive studies, has challenged the previous positivist reading habits. But the literature on the Italian concession in Tianjin that has been produced to date does not seem to reflect this new critical approach.

The second paradigm that I would like to suggest is the application of the idea coined by Benedict Anderson of «imagined community» to the Italian experience both in terms of the colonizers' positionality and the colonial discursive practices. ${ }^{8}$ In his analysis of the concept of nation, Anderson emphasizes the imagined nature of nationalism as a construction created in imagination by printed culture. He argues that before its corresponding political entity - the nation-state - is formed, one must first imagine such an entity: «It is imagined as a community, because, regardless of the actual inequality and exploitation that may prevail in each, the nation is always conceived as a deep, horizontal comradeship».9

Imagining an entity like the modern nation is a way of building a story up around us. This process takes the form of a master narrative so that we are defined as characters in that specific national story. I would suggest extending similar interpretive paradigms to the Italian concession in Tianjin, which has the characteristics of a hybrid community. Foreign and Chinese individuals were living in a small area legally defined as a permanent possession, yet it was a community «imagined» according to different schemes of perception and self-perception. Therefore it was represented at times as a settlement, at others as a colonial space, and at still others as a quarter, a sort of village bridging two worlds. Indeed on the level of personal narratives, the reconstruction of the story of the Italian concession by Consul General Vincenzo Fileti (in his text dated 1921), for example, reveals how the dominant story crafted by the Italian state in the colonial period through its agents, contributed to the construction of an imagined community. ${ }^{10}$ Thus the representative of the colonial state became the embodiment of an alleged success story for the whole nation.

7 Jacqueline Andall and Derek Duncan, «Memories and legacies of Italian Colonialism», in Jacqueline Andall and Derek Duncan, eds, Italian Colonialism. Legacy and Memory, Oxford: Peter Lang, 2005, p.11. See also Ruth Ben-Ghiat and Mia Fuller, eds, Italian Colonialism, London: Palgrave Macmillan, 2005.

${ }^{8}$ By positionality, I intend the situated knowledge produced by the colonizer, which can certainly be seen as a form or knowledge/power.

${ }^{9}$ Benedict Anderson, Imagined Communities, London: Verso Books, 1991, p.7.

${ }^{10}$ Vincenzo Fileti, La Concessione Italiana di Tien-tsin, Genova: Barabino e Graeve, 1921, pp.8-9. 


\section{Historical Origins of the Italian Concession}

With the signature of the «Final Protocol for the Settlement of the Disturbances of 1900» (Xinchou Treaty) on 7th September 1901, following the repression of the Boxer Rebellion, Italy received an allotment of $5.91 \%$ of the Boxer indemnity [26,617,005 haiguan taels. ${ }^{11}$ This was equal to about 1.55 Chinese national (silver) dollars, or 99,713,769 gold lire]. The country also received extraterritoriality privileges in the Legation Quarter in Beijing, as well as the concession, in perpetuity, of a small zone on the northern bank of the Haihe (Hai River) in Tianjin, situated at $38^{\circ} 56^{\prime}$ latitude north and $117^{\circ} 58^{\prime}$ longitude east, on which to develop an Italian concession. More precisely, the Italian concession was set between the AustroHungarian and the Russian concessions, the left bank of the Hai River, the BeijingMukden (today's Shenyang) railway track and the Chinese territory.

There is general agreement between Western and Chinese written sources that the concession in Tianjin was ceded to Italy by the Chinese government on 7 September 1901. Almost a year later, on 7 June 1902 it was taken into Italian possession to be administered by the Italian Consul General as representative of the Italian government. In reality, on 21 January 1901, the Italian troops had already proceeded to establish a military occupation of an area near the railway station. This area accommodated the soldiers who had disembarked from the Royal Navy as part of the international expedition to occupy the city. The Foreign Minister Prinetti gave his «authorisation» to the provisional occupation of territory that had been suggested by the Royal Minister in Beijing Giuseppe Salvago Raggi. This coincided with the immediate formal execution of the order so that, in Raggi's words, «the allotments near the railway station, bordering with those taken by Russia» were occupied. ${ }^{12}$ Therefore, the often quoted date 7 June 1902 refers more to the convention, which validated the fait accompli.

\footnotetext{
${ }^{11}$ The Boxer Rebellion was directed against foreign influence in areas such as trade, politics, religion and technology. The uprising crumbled on August 4, 1900 when 20,000 foreign troops entered Beijing. See Jonathan Spence, The Search for Modern China, New York: W. W. Norton \& Company, 2001,p. 232. The total amount of the indemnity requested by the foreign powers was 450 million taels/gold, and it was approved with imperial edict on 12 May 1901. In the Final Protocol, we find an indication of the correspondence between tael and the other currency, for example, one tael was equal to 3,75 French francs, and 0,30 pound sterlings. See DD, II, n. 121, p. 64. (DD = Diplomatic Documents, in Italian «Documenti Diplomatici sugli avvenimenti di Cina presentati al Parlamento dal Ministro Prinetti», 2. vols, Roma1901, 1902).

${ }^{12}$ Quoted in Arnaldo Cicchiti-Suriani, «La Concessione Italiana di Tient Tsin (1901-1951)», in Rassegna Italiana di Politica e Cultura, n. 31, October 1951, 563.
} 
There is no unanimous consent in the sources concerning the Chinese population living in the area at the time of the transfer: 13,704 according to the 1902 census, around 17,000 people according to Fileti's report, and 16,500 according to Arnaldo Cicchiti-Suriani. ${ }^{13}$ According to a Chinese source, based on the 1922 census, 4,025 Chinese citizens, 62 Italians, and 42 from other nationalities were living in the concession at the time. ${ }^{14}$ According to Gennaro Pistolese, in 1935 the total population was 6,261 , of which 5,725 Chinese and 536 foreigners including 392 Italians. ${ }^{15}$ F.C. Jones, in the few lines dedicated to the Italian concession, says: «The population in 1937 was 373 foreigners and some 6,500 Chinese».16 Judging from these figures, one can deduct two factors: a significant decrease of the population living in the Italian concession from 16-17,000 (1902) to 4-6,000 (1922-1935) and a predominance of Chinese citizens. Nevertheless, Italian sources tend to obscure the presence of Chinese citizens in the concession, relegating them to the role of subalterns. These sources also reveal a progressive apotheosis of an encomiastic and self-reflexive image that was based on successful infrastructural projects that beautified the area, making it a miniature representation of the alleged success of the Italian nation.

Pistolese in particular, when he writes in 1935, argues that, according to more recent estimates, the Italian community in Tianjin would have consisted of about 150 people, instead of 392. But much more than the accuracy of the data, the main point of his article is the emphasis on the fact that «Our concession has a demographic consistency superior to the other concessions in Tien-Tsin». He reports the data of the Japanese concession $(5,000$ people), British $(2,000)$, and French $(1,450)$. This is one of the many elements used by him and by other writers in the Thirties, in line with the Fascist regime's attempt to create a narrative of benign colonialism; to emphasise the outstanding success of the Italian spiritual and civilising mission in this «faraway extension» of the motherland. ${ }^{17}$

By 1943 the concession still had a garrison of circa 600 Italian troops, but on 10 September 1943 it was occupied by Japan; since Mussolini's Italian Social Republic (virtually fictitious at that point) relinquished the concession to the Japanese

13 V. Fileti, La Concession, p.15.

A. Cicchiti-Suriani, «La Concessione », 562.

${ }_{14}$ Nankai Daxue zhengzhi xuehui, ed., Tianjin zujie ji tequ, Shizhengfu congshu series, Tianjing: Shangwu yingshuguan faxing, 1926, pp.6-7.

${ }^{15}$ Gennaro E. Pistolese, «La Concessione Italiana di Tien-Tsin», in Rassegna Italiana, A. XIII, Special

Volume (XLI) «L'Italia e L'Oriente Medio ed Estremo», August-September, 1935, p.306.

${ }^{16}$ F.C. Jones, Shanghai and Tientsin, London: Humphrey Milford for Oxford University Press, 1940 , p.128.

17 G.E. Pistolese, «La Concessione», pp.305-310. 
sponsored Chinese National Government (which was neither recognized by the Kingdom of Italy, nor by the Republic of China). On 10 February 1947 it was formally ceded back to China by post-war Italy.

\section{The Value Added of the Concession}

The symbolic significance of the Boxer Protocol was decisive for Italy in terms of acquisition of national prestige and recognition of Italy's international status. This is particularly true in retrospect, and in comparison with other foreign powers that had already firmly asserted their presence and influence in the Chinese territory. The analysis of the symbolic capital of the Italian gains points to something well beyond modest territorial conquest. First and foremost, following the Protocol, Italy officially joined the other colonial powers in the extraterritorial privileges they had received in the Legation Quarter in Beijing. Furthermore, Italy obtained the authorisation to use the international quarters in Shanghai and Xiamen, as well as the right to maintain a military garrison at the Legation Quarter in Beijing, and another one at the Shanhaiguan fort during the summer. ${ }^{18}$ The only condition was the payment of 2,000 lire per year. The Protocol's military consequences were also particularly significant for Italy. Three factors need to be considered: the recognition of the Italian property of the Dagu anchorage on the estuary of the Beihe, with relevant operations of protection and defence; the semiotic relevance of the names chosen for the garrison houses that Italy was authorised to build and maintain, namely «Italy» in Hangzhou, «Savoia» in Tianjin, «Regia Guardia» (Royal Guard) in the Italian legation in Beijing; and, last but not least, the authorisation to use its soldiers to defend churches, missions, railways, and mines, if necessary.

As for Tianjin, the agreement clearly stated that: «The Italian Government will exercise full jurisdiction in the same way established for the concessions obtained by the other foreign powers», which corresponded to the acknowledgment of the long sought after «equal» treatment of Italy on the same level of the other colonial powers in China. ${ }^{19}$ The agreement was signed by the Director of the Chinese Maritime Customs Tang Shaoyi and Count Giovanni Gallina (the successor to Salvago Raggi), and clearly stated that the concession was ceded, «to promote the

\footnotetext{
${ }^{18}$ During the twentieth century modern Xiamen was also known with the toponym Amoy.

${ }^{19}$ Agreement. Italian text. Translation is mine. Italics added.

On the relations between Italy and China in the XIXth century see Giorgio Bocca, Italia e Cina nel Secolo XIX, Milano: Ed. Comunità, 1961.
} 
development of Italian trade in the northern part of China, and in the Zheli (Chi-li) province in particular». ${ }^{20}$

Considering the concession within the context of the previous experience of repeated failures, which had characterised diplomatic relations between Italy and China from the 1866 bilateral Treaty onwards, the acquisition of the concession assumed for Italy the value of an historical nemesis. Numerous accounts regarding the concession clearly show this element of implicit revenge. Prime Minister Giovanni Giolitti had defined the former unsuccessful Italian attempt, in the spring 1899, to obtain the official Chinese Government's recognition of the Sanmun bay as a naval station, and the Italian influence zone in Zhejiang, as «a waste of a few millions (Lire) and a national humiliation».21 Giolitti had harshly criticized the mistakes made from the beginning to the end and strongly recommended the Foreign Minister not to publish the relevant documents. The rejection by the Chinese Government to accept the 1899 Italian request and the ensuing ultimatum, caused a serious wound in the imagined community of the newly created Italian nation. Particularly since the rejection occurred in an historical moment when all the other foreign powers (Great Britain, France, Germany, but also Japan and Russia) were obtaining concessions and settlements in locations that were strategically important for their political presence and economic penetration in the Chinese territory. The wound was even more profound because the 1899 Italian request and ultimatum were not supported by Great Britain: a move that revealed that other foreign powers were not keen on seeing Italy exerting its influence in China. ${ }^{22}$ Cicchiti-Suriani, writing in 1951 to commemorate the fiftieth anniversary of the acquisition of the concession, pointed out that «After the unfortunate prelude of Sanmun, that gesture represented the epilogue of the 1900 international events».23

The voices of the advocates of the Italian commercial interests in China had been particularly intense in the decade 1890-1900, both at the academic level, including Prof. Ludovico Nocentini from Rome University who wrote articles to launch petitions from the pages of magazines such as Nuova Antologia, Rivista d'Italia and Rivista Geografica Italiana, and amongst journalists such as Giovanni Vigna del Ferro. ${ }^{24}$ Even local newspapers, such as the Corriere Mercantile (Mercantile Courier)

\footnotetext{
${ }^{20}$ Agreement. Italian text.

${ }^{21}$ Giovanni Giolitti, Memorie, vol. I, p.154. Giolitti was the Italian Prime Minister from 1904 to 1914, during the so-called Parliamentary dictatorship.

${ }^{22}$ See G. Bocca, Italia e Cina, pp.157-188 ; G. E. Pistolese, «La Concessione», pp.305-306.

${ }^{23}$ Cicchiti-Suriani, «La Concessione», p. 562.

${ }^{24}$ See Lodovico Nocentini, L'Europa nell'Estremo oriente e gli interessi italiani in Cina, Milano: Hoepli, 1904.
} 
from Genova, supported this cause, becoming the official voice of the Genovese ship-owners who were promoting the image of China as a land of opportunity. ${ }^{25}$

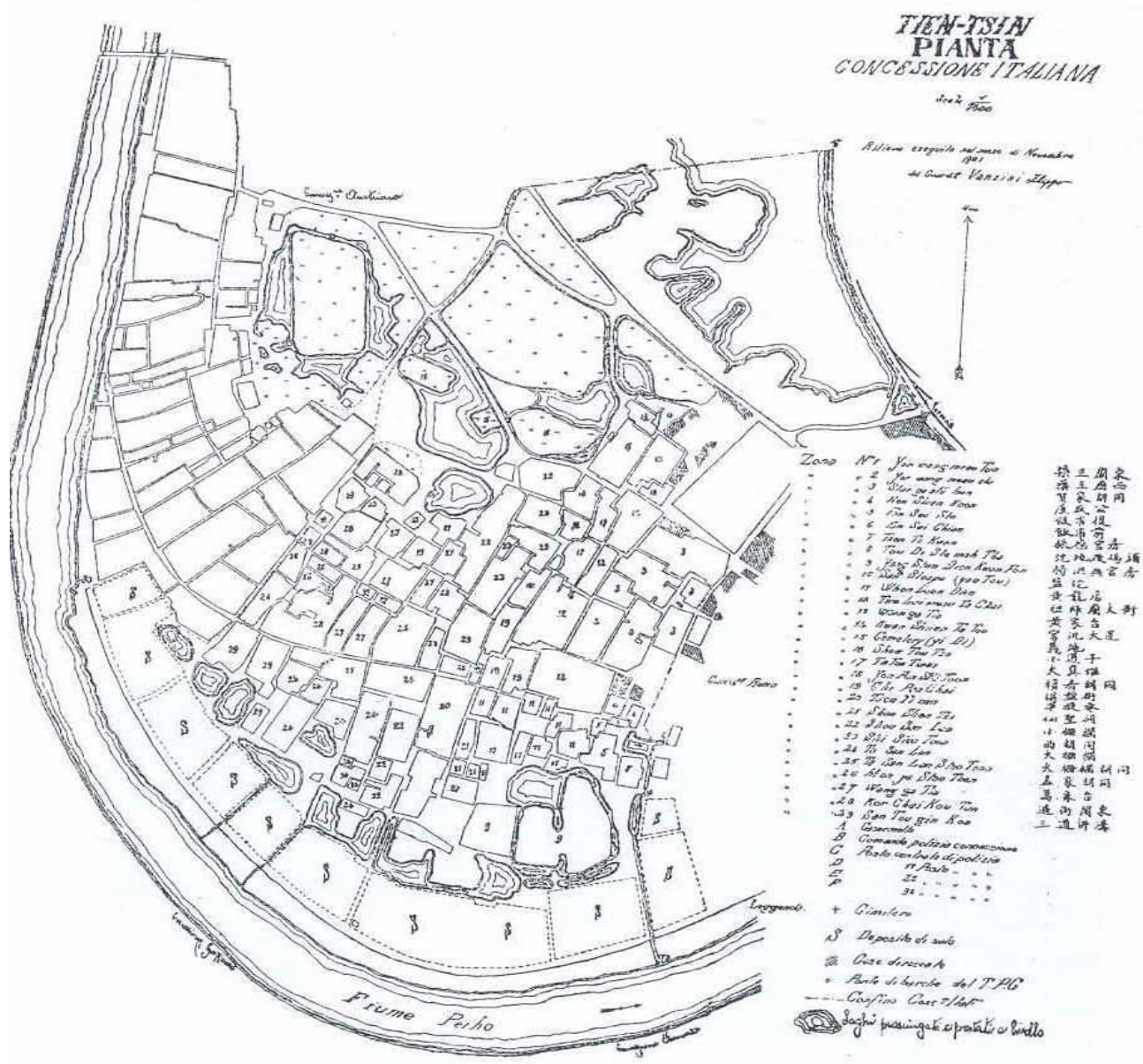

Figure 2. Map drawn in November 1901 by the coastguard Filippo Vanzini. In Vincenzo Fileti, La Concessione Italiana di Tien-tsin, (Genova: Barabino e Graeve, 1921), p.13.

\section{The Area of the Concession and the Role of Tianjin}

The majority of the sources state that the area originally ceded to the Italian Government consisted approximately of half a square kilometre. ${ }^{26}$ Giacomo De

Giovanni Vigna del Ferro, «L'Italia nella questione cinese», Rivista politica e letteraria, October 1901.

${ }^{25}$ Among the editorials published in the Corriere Mercantile, «La Politica Italiana in Cina», 3 May, 1899,

«Partenza delle truppe per la Cina. Entusiastiche dimostrazioni popolari», 20 July, 1900. 
Antonellis affirms that it consisted precisely of 447.647 square meters, while a source attributed to the Department of Architecture of Tianjin University refers to

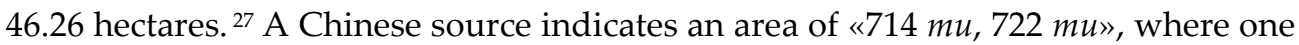
$m u$ corresponds to 0.0667 hectares (therefore, 47.62 ha. or 48.15 ha. respectively). ${ }^{28}$ Another Chinese source reports the Italian concession at the time of its establishment (1902) as $771 \mathrm{mu}\left(51.42\right.$ ha.). ${ }^{29}$

The overall area could be divided into four parts. Proceeding from the south (where the river flows) to the north (where the railway station is located) the territory consisted of four parts:

1. A higher rising area of approx. $100,000 \mathrm{sqm}$. used as a salt deposit. Consul Fileti explains that due to the excavation work all around the salt deposit, a series of ditches had been created, which quickly became "stinky (pestilenziale) pools where the village boys used to wash themselves»; $; 0$

2. The Chinese village, approx. 200,000 sqm., in the centre of the concession area, with approx. one thousand dwelling places (Navy Lieutenant Mario Michelagnoli reports 867 houses), mainly huts, built by the salt workers. ${ }^{31}$ The description of these huts offered by Fileti reveals the degree of poverty of the dwellers: «misery», «poverty» and «indigence» are the words used in the paragraphs describing them), 17,000 Chinese approximately.

3. North of the village there was the worst area consisting of wetland, where the water could be as deep as 3-4 metres, completely frozen in the winter.

4. On the more elevated parts of this wetland the dwellers used to bury their dead, so the place had assumed the aspect of a «vast abandoned and flooded cemetery». Generally, in the Italian descriptions this fourth part is referred to as «the problem of the cemetery».

Italian sources reveal a continuous insistence on the negative conditions of the area destined to become the Italian concession. Interestingly, similar descriptions also

26See: G. E. Pistolese, «La Concessione», p. 306, among others.

${ }^{27}$ Giacomo De Antonellis, «L'Italia in Cina nel secolo XX», Mondo Cinese , n¹9, July-September, 1977, p.52.

Quoted in a source available online, «Nine Concessions in Tianjin»,

http://www.wayabroad.com/tianjin/text/text23.htm (accessed 21 April, 2006).

${ }^{28} \mathrm{Li}$ Wenxin, «Yizujie», in Tianjinshi zhengxie wenshi ziliao yanjiu weiyuanhui, ed. Tianjin zujie, Tianjin: Tianjin Renmin Chubanshe, 1986, p.135.

${ }^{29}$ Tianjin Shehui Kexueyuan Lishi yanjiousuo, Tianjin jianshi, Tianjin: Renmin Chubanshe, 1987, p.209.

${ }^{30} \mathrm{~V}$. Fileti, La Concessione Italiana, p.14.

${ }^{31}$ Reported in Sulla Via di Tianjin: Mille Anni di Relazioni tra Italia e Cina. Un quartiere Italiano in Cina, eds

Nicoletta Cardano, Pier Luigi Porzio, Roma: Gangemi, 2004, p.26. 
characterise the other concessions contained in non-Italian sources. In the case of the British and French concessions obtained in 1860, for example, the concessions are described by Alexander Michie, editor of the newspaper Chinese Times as:

«... dreary grounds which contained within their areas junk docks, small vegetable gardens, mud heaps, hovels of fishermen, sailors and others, whose wretched groups of squalid huts were divided from each other by narrow tidal ditches which were bordered by meagre and ill-kept footpaths. The sites of the two settlements were foul and noxious swamps, around them, on the dryer ground, were the numerous graves of many generations of the people. ${ }^{32}$

The description of the French concession also contains a derogatory portrait of the residents: apparently it was «a wretched terrain given up to pools, cabbage gardens, hot pits for storing fruit and vegetables, and a rowdy, sinful, and criminal population». ${ }^{33}$ Similar is the description of the American concession, which according to Michie, still had no houses and was mostly occupied by ice pits. ${ }^{34}$

F.C. Jones emphasises the poor conditions of the concessions area, by describing the continuous danger of flood, and the cost of maintaining the high mud banks. He mentions for example, the so-called extra-mural extension in the British concession, which would have required the moving of two hundred million cubic feet of river silt. Jones comes to the conclusion that «the Chinese authorities might well have had cause for satisfaction in having induced the foreigners to agree to accept a lease of territory which was of negligible value». ${ }^{35}$

This recurrent motif sounds instrumental in justifying the occupation of the concession areas on the one hand, and in emphasising the significant achievements of the foreign powers in their relevant areas on the other. It is hard to believe that the Qing Government was so willing to accept the conditions of the 1860 Convention, just because the foreign powers would have occupied territories of socalled «negligible value». The location of Tianjin was strategically important for the commercial penetration of China. Situated in the densely populated and productive North China Plain, on the Haihe at the northern terminus of the Grand Canal, and on the axis Dagu-Tianjin-Beijing axis, Tianjin has traditionally been the port of Beijing, which is only $120 \mathrm{~km}$ (72 miles) to the north-west. In some sources, the information relevant to the geopolitical importance of Tianjin refers to the Beihe

\footnotetext{
${ }^{32}$ Alexander Michie, editor of the Chinese Times, the first newspaper in Tianjin, quoted by O.D. Rasmussen, Tientsin - An Illustrated Outline History, Tientsin: Tientsin Press, 1925, p.37. ${ }^{33}$ Alexander Michie.

${ }^{34}$ Alexander Michie.

${ }^{35 F}$.C. Jones, Shanghai and Tianjin, p.119.
} 
and not to the Haihe, saying that «the city is situated about 37 miles $(60 \mathrm{~km})$ up the Peihao River (Beihe) from the ocean at Taku (Dagu) ».36 The Beihe, the Yongtinghe and other smaller tributaries converge at Tianjin to form the Haihe. Historically, the commercial, military, and ultimately strategic importance of Tianjin can be recognised on two levels. Domestically, Tianjin's relevance is demonstrated by the construction of the walled city during the reign of Ming Emperor Yongle (1425). Internationally, its significance is revealed by the report of first Dutch Embassy to Beijing (1655), whereby Tianjin is depicted as a locality «very populous and so full of trade, that hardly the like commerce is to be found in any other city in all China; for whatever vessels are bound for Peking from any other part of China, most touch here, which occasions an extraordinary traffic for shipping, which lye continually before the city». ${ }^{37}$ Its original name Tianjinwei can be translated as «the guard of the bridge to heaven» clearly referring to its geopolitical location and its role of protecting Beijing, where the Emperor or «Son of Heaven» (tianzi) was ruling. During the nineteenth century, through cycles of destruction and reconstruction, Tianjin developed from being a vibrant ancient walled Chinese city to becoming arguably the most important commercial city in Northern China. This was mainly due to its strategic location in terms of economic domain, access and transport: Tianjin became not only the hub of the expanding railway network, but also a major international trading city with shipping connections to all parts of Asia.

\section{Concession or Neighbourhood}

The sources that I have collected and used for this research are texts, images, drawings, photographs, maps, all related to the Italian concession. The first source that I would like to analyse is a recently published exhibition's catalogue, whose original Italian title could be translated in English as follows: "On the Road to Tianjin: One Thousands years of relations between Italy and China. An Italian neighbourhood in China». ${ }^{38}$ The Chinese title which accompanies the Italian one on the cover is much more concise and coincides with the subtitle of the Italian one: «Yige Yidali qu zai Tianjin (An Italian Neighbourhood in China)». On the cover of the book appear Japanese children, clearly (and embarrassingly) mistaken for Chinese.

The book undoubtedly builds on previous scholarship on the Italian concession, and offers its readers a good collection of photographs and archival documents

${ }^{36}$ http://www.geocities.com/Eureka/Plaza/7750/tientsin01.html, retrieved on 2 May, 2006.

${ }^{37}$ O.D. Rasmussen, Tientsin, p.9.

${ }^{38}$ N. Cardano, P. L. Porzio, eds., Sulla Via di Tianjin. 
relating to the Italian concession from 1902 to the 1930s. The historian however, cannot refrain from noticing a continuous attempt to obliterate the idea that Italy, for almost half a century, had a concession (zujie) in Tianjin, and not a neighbourhood. The compound word zujie does not indicate a real colonial status (since «colony» is translated in Chinese as zhimindi, where the verb zhi literally means to breed, to grow, to multiply) or a settlement, I believe it is very important to remember that the compound word zujie still clearly embodies the idea of «leased territory» and includes the concept of demarcating an area. ${ }^{39}$ Chinese historians emphasise that, from an administrative, juridical, police, and fiscal perspective, the concessions were «states within the state» (guozhongzhiguo). ${ }^{40}$ The linguistic replacement of «neighbourhood» (e.g. in Chinese the generic «qu» as opposed to zujie), belongs to a typical colonial process of renaming, which implies a modification of the form in order to mystify the content and context. This process produces an edulcorated image of the colonial presence, and is an essential component of what I define as «benign colonialism», which aims at offering an over-positive and often narcissistic image of Italian colonialism. In fact $q u$, which is here translated as neighbourhood, literally means «area, district, region» (quyu) while the Italian term «quartiere» conveys both the sense of clearly defined residential district and the idea of a community characterized by some forms of vicinity and/or familiarity. It indicates an area or district where the inhabitants share the fact of co-inhabiting a space and, at times, certain habits and customs, or might know or somehow communicate with each other through formal or informal channels. The attempt to show that, in reality, the Italian concession was just a «neighbourhood» seems to be in line with the declared two-fold aim of the project: «to encourage and expand the commercial relations between the two countries, and export and diffuse the best image of urban, architectonic, and artistic culture at that point of time to a country so faraway from Italy like China».41

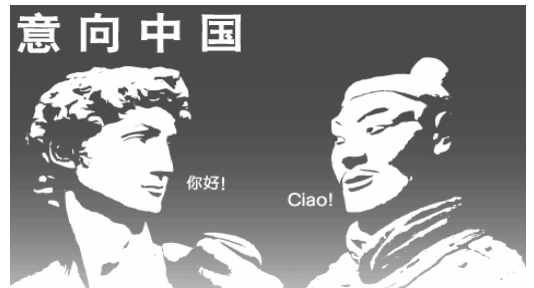

Figure 3. Logo of «2006 The Year of Italy in China», www.yidalinian.org, retrieved 10 June 2006.

${ }^{39}$ The term $z u$ means «to rent/lease», jie means «boundary», from the compound guojie (boundaries of a country).

${ }^{40}$ Shan Keqiang, Liu Haiyan, Tianjin: Zujie Zheshui Yanjiu, Tianjin: Tianjin Renmin Chubanshe, 1996, p.1.

${ }^{41}$ N. Cardano, P. L. Porzio, eds., Sulla Via di Tianjin, p.7. 
The Italian concession «imagined» as an «Italian neighbourhood» allows its representation as «the witness of the implementation of a common work between Italians and Chinese that today, after more than sixty years, is somehow rediscovered and re-evaluated in its value and its own meaning». Two questions which lead me through the reading of these materials point precisely in the direction of their «value» and «meaning». The emphasis on the «common work of Italians and Chinese» when the hybridization is clearly omitted from the Italian sources, allows for the creation of the fictitious representation of a «neighbourhood», that would have been «received» from the Chinese Imperial Government, masking the tones of the Italian colonial experience in China. ${ }^{42} \mathrm{But}$ this approach is in line with the current Chinese official intention to represent the concessions' time as the beginning of Tianjin's internationalisation, capitalising on those seeds of global capitalism instead of demonising them. Recently the Tianjin Municipal Government has started a process of renovation of the former Italian concession that is today called "Yi(dali)shi fengqingqu», an expression (whose translation could be «scenic area or neighbourhood of Italian style») that obliterates the colonial past and aims at marketing the former colonial buildings in order to attract foreign capital and domestic customers. ${ }^{43}$

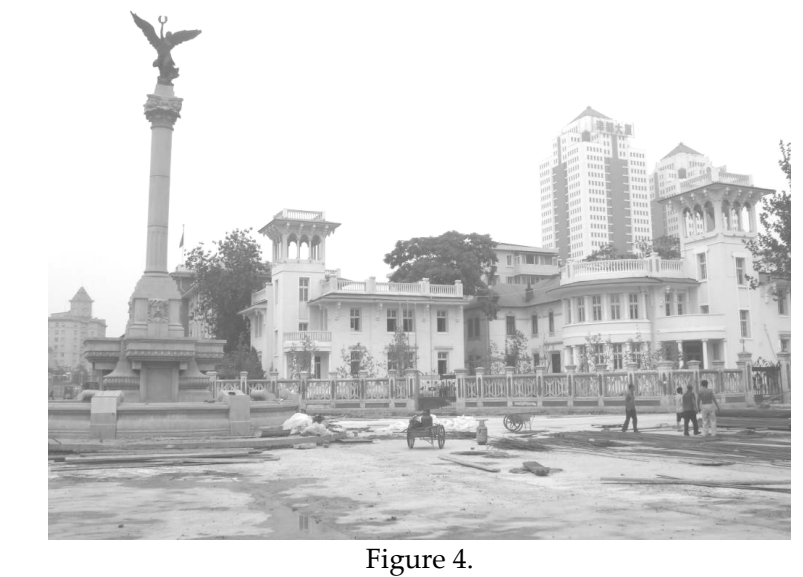

Building, renovation and restoration in the former Italian concession.

Photograph taken on 25 June 2006.

${ }^{42}$ N. Cardano, P. L. Porzio, eds., Sulla Via di Tianjin, p.7.

${ }^{43}$ When I discussed the meaning of the compound word fengqingqu with some Chinese colleagues, we were also noticing the strange resonance with the compound hongdengqu which refers to the «red light district». The obliteration of the historical past via renaming it and the attempt to reclaim the colonial space via its commodification can be indeed a form of prostitution.

Tianjin Yidali fengqingqu Jianzhu yu zhengxiude lishi yu huigu, Beijing: Ed. Graffiti, 2006. 


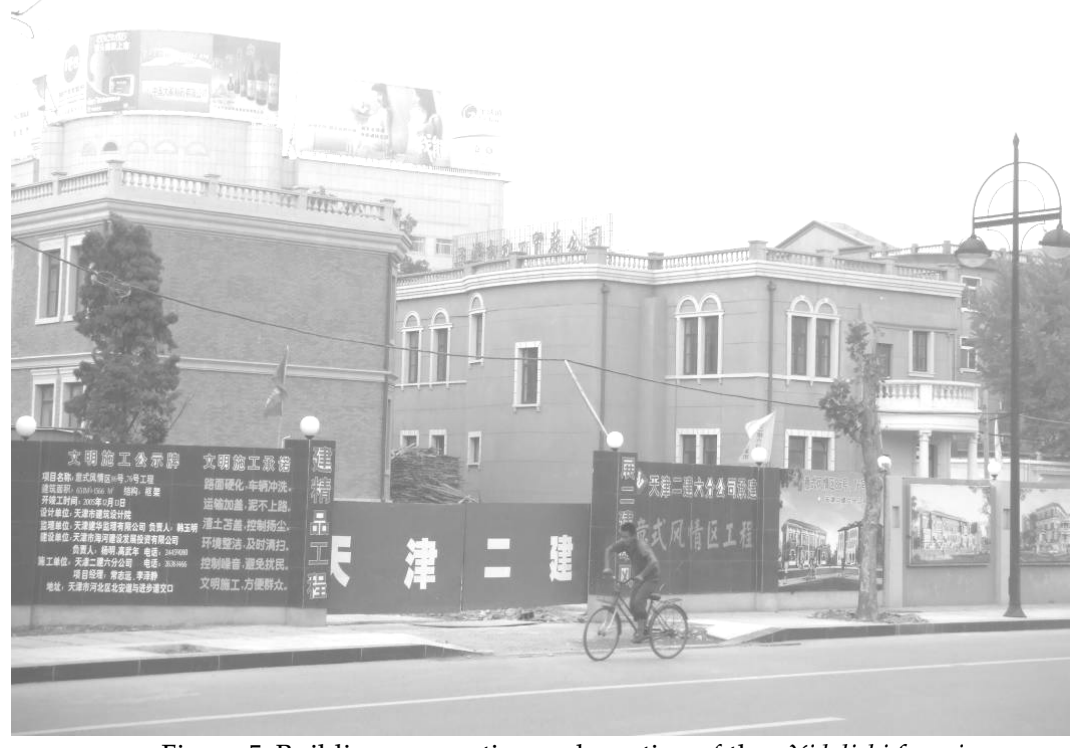

Figure 5. Building, renovation and creation of the «Yidalishi fengqingqu», Photograph taken on 25 June 2006.

\section{The Reorganisation of the Concession}

The various sources reveal different re-presentations of the area destined to be the Italian concession. The Royal Minister in Beijing, Salvago Raggi, thought it was the best area, clearly indicating prospects for rapid and successful development. The Italian Consule in Tianjin Cavalier Poma did not agree with this re-presentation, since the area consisted of a populous Chinese quarter, a cemetery, and wetlands, which did not seem to be very promising. Apparently, Vessel Lieutenant Valli, commander of the Tianjin garrison, was the person responsible for the military operations and he chose «to occupy the next best thing" (the Italian expression is «quanto restava di meglio»), probably the only one left behind by the other colonial powers. Some of the Italian sources indicate that the British would have reserved for themselves the best area. ${ }^{44}$ One of the most imminent problems was how to find the financial resources to solve the problem of the cemetery and reclaim the wetland. There were two channels to be explored: public funding and private forms of investment.

${ }^{44}$ See Roberto Bertinelli, «La Presenza Italiana in Cina dal 1900 al 1905», Rivista di Studi Orientali, vol.57, 1983, p.34. 
In 1905 the Italian Foreign Ministry approved the town plan for the Italian concession that was drawn up by lord lieutenant Adolfo Cecchetti. The leveling of the territory was considered a priority, implying both the removal of the cemetery and the drainage of the marshes. On the $5^{\text {th }}$ of July 1908, a public auction programtried to attract potential buyers for the allotments of the Italian concession. ${ }^{45}$ At the same time, the police regulation were issued, together with the first «Building Code» for the concession (here referred for the first time with the Italian term for «quarter» or «neighborhood»), signed by Consul Da Vella. ${ }^{46}$ The Building Code clearly indicates the intention to annihilate all the signs of Chinese identity, and replace it with the superimposition of a layout of Western style roads, maximum two-storey houses, and «European style, elegant («signorile» in Italian, lett. gentlemanly) residences». The Building Regulations specified that:

«All the buildings facing the Vittorio Emanuele road must be in European style and exclusively occupied by Europeans of good character and standing or by Taotais or other high Chinese Officials who must obtain a permit from the Royal Italian Consulate.» ${ }^{47}$

The other rules regarding the buildings stressed the importance of respecting the foreign or, in other cases, semi-foreign style. They also entrusted the Consul with «full power to order any alteration of any building not put up in accordance with the plan rendered to him for sanction; or order any repair with regard to safety and hygiene». Moreover it is clearly specified that, «The Consul will have full power to have any house or building pulled down» should it not be strictly in accordance with the Building regulations. ${ }^{48}$ In general, one can observe in the regulations a tendency to associate class status with morality and hygiene; alongside the enforcement of restrictions on the Chinese inhabitants, who also had to obtain sanction «previous to weddings, funerals or any other function» (XXIV, 10). Other examples of the association between morality-hygiene and «modernity» are as follows: «All kinds of public entertainments must be authorised by the police» (XXIV, 13), while a special permission is required to open Chinese theatres (XXIII) and the proprietors must «guarantee the morality of the artists as well as the public

${ }^{45}$ See Royal Italian Consulate, «Tientsin-China. Sale by Auction of land in the Royal Italian Concession in Tientsin, 6 July 1980».

46See ASD MAE, Serie Politica P Cina 1891-1916 b. 426-427.

${ }^{47}$ Royal Italian Concession in Tientsin. Local land Regulations and General Rules, Building Regulations, article 1. Taotai refers to an official at the head of the civil and military affairs of a circuit, which consists of two or more or territorial departments $(f u)$. A possible translation is «Intendant of circuit». Foreign consuls and commissioners associated with taotai as superintendants of trade at the treaty ports are ranked with the taotai.

${ }^{48}$ I Royal Italian Concession in Tientsin. Local land Regulations and General Rules, articles III, XI. 
safety». Furthermore, it was established that the "Chinese inhabitants on the unexpropriated portion of the concession» must keep their houses clean, including «the portion of the road in front of their houses» (XXIV, 1). Another example of discrimination was the fixed rule establishing that «Any native of bad character may be expelled from the concession» (XXIV, 13), which indicates a high level of discretion.

The 1908 public auction encountered some difficulties, and it became clear that private sponsorship could only have followed the public investment, and not vice versa. It was only in 1912 that the Italian Government finally decided to allocate 400,000 Lire to promote the development of the Italian concession. ${ }^{49}$

The decade 1912 to 1922 was characterised by the creation of all the streets in the Italian concession, including the building of the Consulate (1912), the conceptualisation and construction of the hospital (1914-22), and the creation of the municipal council building (1919).

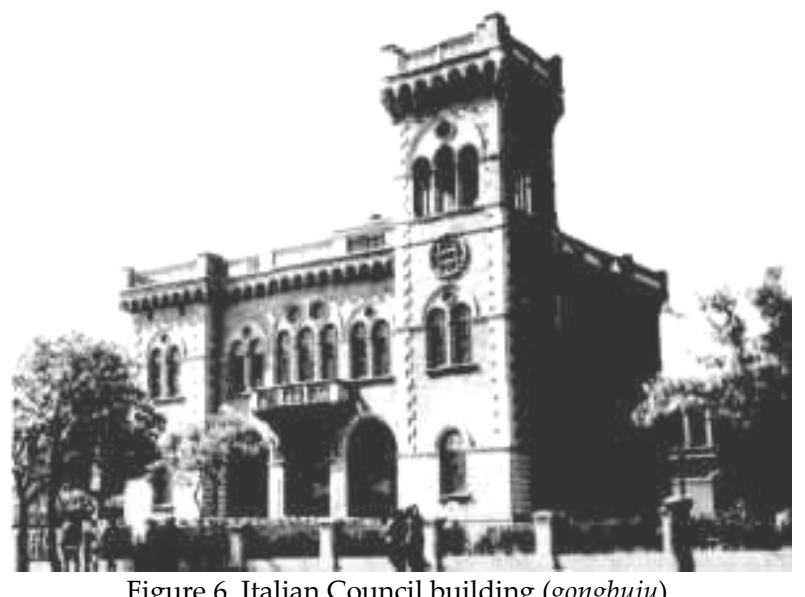

This was a time when the Italian concession became the imagined community that is depicted in extremely positive terms in Italian sources. In their comparison between the past and present of the concession, Italian sources utter in unison the praises of the enlightened city planning intervention that totally transformed what Count Carlo Sforza, among others, described on 22 April 1912 as: «a whole Chinese village, and around it, rotten («putrefascente» in Italian) marshes, and as far as the eye can see layers and mounds of Chinese caskets» into a deeply contrasting image where «the wetland had been reduced to a minimum, and not a single tomb can be

${ }^{49}$ The Law n. 707 dated 30/06/1912, authorised the advanced payment from the Deposit and Loan Fund. 
found in the concession». The concession assumed «the role of showcase of Italian art, with the import of decorating and building materials from the motherland», especially for «the most representative objects, like the public buildings and the monumental fountain located at the centre for Queen Elena Square». 50

It was the urban architecture in particular, with the new streets layout and European style houses, which gained unconditional praise. Through the analysis of Italian sources, the often mentioned building hosting the Consulate - described by Sforza as a «grazioso villino (nice small villa)» - as well as the «villino (small villa)», which housed the Italian Council, appear to be the best examples of colonial buildings as symbols of power: they defined a spatial identity and enforced a national discourse in the hyper-colonial space of domination. What tends to be obliterated is the history of the various locations of the Italian Consulate, which was actually a sort of odyssey. Originally the Italian Consular office was hosted in the British concession, later, from 1902 to 1912, the Consulate was lodged first in a Chinese house, then in the military barracks area. This was a building developed by the Navy Command and described as «a perfectly presentable pavillon, considering the current situation of Tianjin, in the provisional state of things here, and until the time will allow us to come closer to the way of being of the other Consulates».51

The «villino", which housed the Italian Council, was built by the company belonging to the long time resident of Tianjin Egidio Marzoli, in neo-renaissance style. ${ }^{52}$ It clearly echoed the fifteen century Italian villas and was characterized by square shape, consistent floor plan, and a hip-roof surmounted by a turret. This building was seen as the proper affirmation of the Italian presence in Tianjin. In 1925, the architect Bonetti, a resident of the concession, drew up a plan to expand the building by means of a heated verandah, to be used as a reception room. This building was destroyed around 1990, while the former Italian Consulate building has become the headquarter of the Chinese People's Political Consultative Conference of Hebei District (中国人民政治协商会议).

${ }^{50}$ N. Cardano, P. L. Porzio, eds, Sulla Via di Tianjin, p.34.

${ }^{51}$ Quoted in Sulla via di Tianjin, p.36.

${ }^{52}$ The equivalent of this style in England is the so-called «Renaissance Italian Palazzo», inspired by John Ruskin's panegyrics to architectural wonders of Venice and Florence a shift occurred around 1840 since «the attention of scholars and designers, with their awareness heightened by debate and restoration work», Rosanna Pavoni. Reviving the Renaissance: The Use and Abuse of the Past in Nineteenth-Century Italian Art, Cambridge: Cambridge University Press, 1997, p.73. 


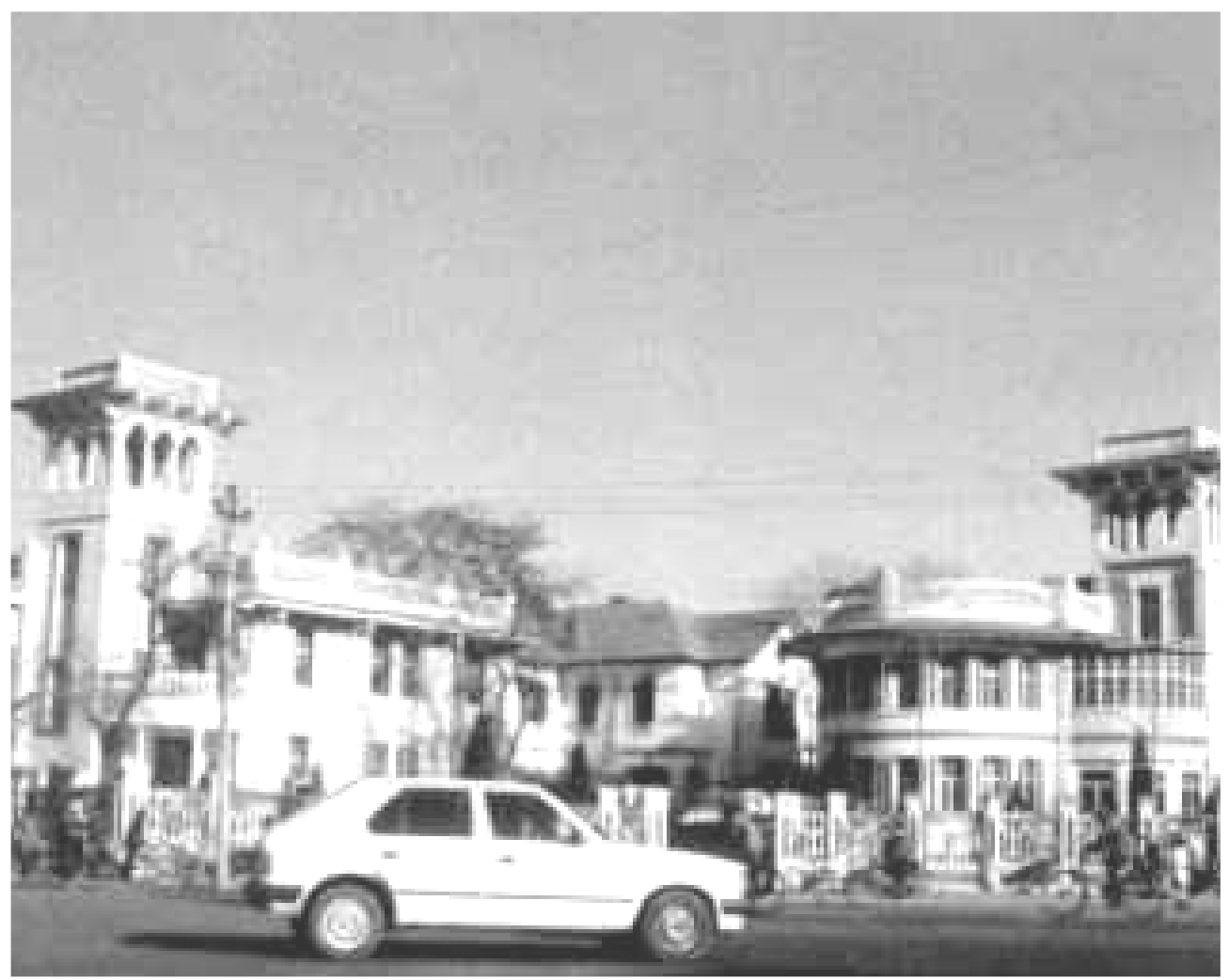

Figure 7. Villas in Italian renaissance style (1908-1916), located around the piazza in the ex-Italian concession, Minzulu and Ziyoulu. (http://www.wayabroad.com/tianjin/gaone/gaone54.htm) Retrieved 3 June 2006.

Each concession developed its residential area for the expatriates of the colonial power (and in some cases for wealthy Chinese citizens), using building styles that were reflecting, reproducing and imposing the stylistic traditions of each individual country. In the case of Italy, the export to China of the neo-renaissance style can be interpreted as a way of affirming its prestige and its positioning as a colonial power on the same level of the others. In fact, a self-consciously «Neo-Renaissance» manner had rapidly expanded and become popular throughout Europe, especially between 1840 and 1890. By the end of the XIX century this style was a commonplace sight on the main streets of thousands of towns, large and small around the world. The Italian neo-renaissance style was present also in the French concession: an example is the church of St. Louis, which combined a Florentine neo-renaissance interior with a roman renaissance façade. Further examples could be found in the 
former Zhong Sun Bank and Hua Kua bank. These buildings are both situated today on Jiefangbeilu (North Liberation St.).

The creation of the concession as a sort of miniature Italian architectural display, which was so familiar to the other nations, raised the international profile of the newly created Italian nation, both internationally and domestically. Foreign journalist like H.G.W. Woodhead, in 1934, stated:

«The German concession ... was the most favoured residential area for foreigners of all nationalities. ... The British concession and extension contained the most important foreign banks, offices and shops, and a considerable Chinese population ...The Italian concession ... was becoming the most popular centre for the palatial residences of retired Chinese militaries and politicians. $»^{53}$

In 1985, with his comparative study of Cape Town and Tianjin, geographer John Weston pointed out that «It did prove somewhat disconcerting on a first visit to a Chinese city to encounter architecture reminiscent of inner Paris, suburban Surrey, or baroque Salzburg in the former concession areas». ${ }^{54}$ In the literature of Italian colonial period, and even afterwards, the sense of «disconcert» is totally neglected and replaced by an assertive narcissism, especially during the fascist era. ${ }^{55}$

The analysis of an urban image construction and deconstruction process, before and after 1949, is a privileged medium, through which it is possible to understand not only the material transformation that affected a particular area of Tianjin; but also the complex politics of reproduction of space in the Tianjin concessions area. The explicit and implicit values dominating the Italian colonial discourse were also clearly unmasked and revealed through the choice of new names for the concession's streets. For example, the choice of names such as Matteo Ricci (today's Guangmingdao, meaning Road of Light - as opposed to darkness), for the road where the barracks, dedicated to national «hero» Ermanno Carlotto, were located, reveals the intention to use all the historical precedents to legitimate the existence of a long term relation between Italy and China. ${ }^{56}$

${ }^{53}$ H.G.W. Woodhead, A Journalist in China, London: Hurst and Blackett, 1934, p.65.

${ }^{54}$ John Weston, «Undoing the Colonial City? », in Geographical Review, vol. 75, no 3, July 1985, p.341. Italics added.

${ }^{55}$ See G.E. Pistolese, «La Concessione», pp.305-310; Ugo Bassi, Italia e Cina: Cenni Storici sui rapporti diplomatici e commerciali, Modena: E. Bassi \& Nipoti, 1929.

${ }^{56}$ Carlotto was the naval lieutenant who had died in Tianjin on 15 June, 1901 while defending, together with a group of navy men, the so-called Italian Consulate. De Antonellis informs us that twelve Italian soldiers died in the military expedition 1900-01. 
The process of physical demolition, rehabilitation or historical and political reappropriation of the colonial buildings is particularly significant in the case of Tianjin, as demonstrated also by the renaming of the streets in the concession areas. Some of the most interesting buildings from the concession era are located on what is called today Jiefangbei $\mathrm{Lu}$, which runs parallel to the river. Some of the most fascinating Italian style villas from the period 1908-16 are located in what are called today Minzulu (National Rd.) and Ziyoulu (Freedom Rd.), clearly renamed after 1949. According to the new geography of space embodied by today's map, the Italian concession is simply the space contained between Beiandao (the Road of the Northern Peace) and Ziyoudao (Liberation Road) on the north, the Haihe on the south, Wujinglu (St. of the Five elements) on the east and Xinglongjie (Flourishing St) and Jinguodao (National Foundation St.) on the northeast. The new names of these streets clearly indicate the reconquest of the former concession's space in post-1949 China.

\section{Images of Benign Colonialism}

During the fascist period the hagiographically tinged master narrative of benign colonialism reached its climax, with a particular emphasis on the dichotomy between the bleak prospects of the past and the unique achievements of the present in the concession's territory. The past was always portrayed as backward and hopeless, while the present was represented with all the ingredients of a «modernity» conceived as superimposed progress and self-reflexive improvement. In 1936, in line with the spirit of the Italian fascist regime's dream of Empirebuilding, the engineer Rinaldo Luigi Borgnino wrote an enthusiastic and celebratory article where he argued against the possibility of ceding the territory back. ${ }^{57}$ Borgnino believed that the legitimacy of keeping the concession was based on the highly civilizing motivations demonstrated by the Italians, as revealed by the progressive «evolution» of that «small territory». The key adjectives used by Borgnino in his description of that area before the Italian intervention are: miserable, noxious, desolated and sad. But after the Italian acquisition of the area what appears is the image of the Italian concession as a stage display of «Italianness» and as a model of modernity and hygiene. The achievements emphasized by Borgnino are advanced civil engineering and infrastructural projects: large roads, elegant buildings, a modern hospital, the availability of electricity and potable water in all

\footnotetext{
${ }^{57}$ On 9 May, 1936, Benito Mussolini proclaimed the foundation of the Empire. This event occurred three days after the Italian troops, commanded by Marshall Badoglio, had entered Addis Abeba after the eight-month long military occupation campaign of Ethiopia.

R. Borgnino in «La «Concessione» Italiana in Cina», Augustea, 1936, pp.363-366.
} 
houses, the advanced sewage system, and the public landscaping. Borgnino mentions a local British newspaper which would have defined the newly created Italian concession as «the most pleasant residential neighborhood among all the concessions». ${ }^{58} \mathrm{He}$ adds that the bordering concessions were stimulated to implement similar measures to improve their overall aspect and conditions. The final aim of Borgnino's article is unmasked in a closing self-commenting note written by the magazine's editor who, in his address to the readers, praises Borgnino's first hand and long term experience in China, and clearly states the following syllogism: «It is necessary to know all the assertions of the homeland, following it everywhere; and the result will certainly be an even stronger pride». ${ }^{99}$

Borgnino clearly had a personal interest in the production of a successful image of the Italian concession, since he was supervisor of the works for the hospital building, which was inaugurated on 21 December 1922, following the drawings of engineer Daniele Ruffinoni. Borgnino was also in charge of the drawings of the Italian Municipal Council building. He conceived these as «creating an example, the most complete, of Italian art, a showcase of thought, technique and materials, a representative building in the most comprehensive sense of the term».60 In his article, Borgnino used most of the information contained in the official report, written by Consul Fileti in 1921, but intentionally decided to shift from Fileti's emphasis on the economic opportunity for the Italian companies (represented by the penetration in the Chinese «large and virgin market»), to an emphasis on the buildings. ${ }^{61}$ Since these represented signs of distinction and prestige within the Italian concession, and indicated the success of the «Italian spirit». Considering his personal involvement in the creation of the concession, his tone and selective approach are an indication of a self-congratulatory attitude. The most significant element of Borgnino's account is, in my opinion, that his attempt to avoid the colonial theme reveals the significant anxieties about Italy's imperial identity.

Another recurring theme of the literature on the Italian concession published during the Fascist regime is the representation of Italy as playing the lead role

${ }^{58}$ R. Borgnino, p.365. The mystification of the concession as a neighborhood was therefore a colonial rhetorical trope.

${ }^{59}$ R. Borgnino, p.366.

${ }^{60}$ Quoted in Sulla Via di Tianjin, p.44.

${ }^{61}$ «[China] is a vast virgin land for economic exploitation that can be opened to human activity and the effort to overcome the difficulties is well justified ... all the nations that feel strength, due to their commercial and industrial development, have always looked with active and growing interest to the vast and virgin Chinese market and seized every favourable opportunity to breach the wall enclosing such a treasure, to avoid being second or overpowered in the exploitation of that vast new market.», V. Fileti, La concessione, pp.8-9. 
among the other colonial powers. One of the most significant examples of this narrative tendency is offered by the lesson delivered by Dr. Ugo Bassi on «Italy and China» on 26 April 1927 at the Fascist University of Bologna. ${ }^{62}$ Rewriting and appropriating the whole history of East and West encounter, Bassi states that:

«First, even in China, as in every other part of the world are the Italians, who went there for that desire of adventure, for that almost mystical sense of the unknown that in the Middle Ages, pushed the light and well built Italian ships to face new routes, towards Africa or America, searching for the legendary Saint Brandano's islands or looking for gold. ${ }^{63}$

Bassi remembers Giovanni da Pian del Carpine (1245-47), Marco Polo (1261-95), and Matteo Ricci (1552-1610), and reaches its rhetoric climax with the conclusion: «Magnificent progeny this our Italian one, that has offered to the whole world vast continents and new knowledge, affirming herself always and in every field, first among all the others».64

In Bassi's account, England is praised for opening China up and putting an end to the Chinese superiority complex. ${ }^{65}$ When he refers to the international military expedition organized to repress the Boxer Rebellion, Bassi portrays the deceased Ermanno Carlotto like a national hero. ${ }^{66}$ Then, in line with the construction of the predominant narrative of benign colonialism, he emphasises how the Italian soldiers distinguished themselves from the other troops who committed the most tremendous cruelties and created an overwhelming chasm between "white and yellows». According to Bassi: «... the Italians proud as usual of the humanist tradition of their motherland and the Roman civilisation brought to the indigenous people, where they could, aid and rescue».67 The alleged magnanimous behavior of the Italians is contradicted by the primary source offered by the Medical Lieutenant Giuseppe Messerotti Benvenuti (1870-1935). In fifty-eight letters and 400 photographs to the mother he describes the relations between the different military troops, mentioning the killing, the looting and other atrocious excesses, and in the end he sadly recognises that:

${ }^{62} \mathrm{Ugo}$ Bassi, Italia e Cina. The same author had previously written on the Italian colonial policy in Africa and the government of the colony in Libia. See Ugo Bassi, I Parlamenti Libici (1924), Cronache di politica coloniale (1928).

${ }^{63}$ Ugo Bassi, p.9.

${ }^{64}$ Ugo Bassi, p.10.

${ }^{65}$ Ugo Bassi, pp.12-13.

${ }^{6}$ Ugo Bassi, p.15.

${ }^{67} \mathrm{Ugo}$ Bassi, p.16. 
"If our soldiers did less harm than the other armies it is due to the fact that, even though they (the Italians) always went everywhere, they always arrived there late, when the villages had already been burned and plundered. The few times they arrived on time, they behaved like the others. ${ }^{68}$

The point that Bassi is reiterating echoes Fileti's 1921report: Italy could not miss the opportunity to mark off China «as an actor and observer in that world where probably new global destinies were developing». ${ }^{69} \mathrm{His}$ whole description is definitely connotated by a strong sense of patriotism and aims at defining the Italian concession as a showcase of the Italian most remarkable achievements, such as the urban architecture, the hospital, and last but not least the schools. In Bassi's lecture one can really detect the positive affirmation of the rhetorical trope of «Italianness» (or «Italian spirit»). Thus the concession became the ideal ground for experimentation and reinvention of the collective identity of Italy as a glorious and unified nation. Bassi unconditionally praises the Association of the Italian Missions as "Centres of Italianness», and mentions not only Tianjin, but also the efforts of the Italian missionaries in Hankou, after their forced departure from Nanjing. The metonymic trope of the Italian spirit is embodied, for Bassi, in the Catholic cathedrals: these masculine symbols of conquest of the space between earth and heaven, that «recall the faraway motherland, in the simple but typically Italian style» - even though they might be disconcerting in a foreign cityscape. Bassi praises the «silent apostles» in the Chinese and other foreign lands, who act «in the name of Christ, but also in the name of Italy» and «turn on the vivid human light, Latin, in the lighthouses of the most remote lands».70 At this point of his speech Bassi clearly states, although in parenthesis, what he considers as the most profound motivation of the Italian spirit. This is also the climax of his lecture and the most important message that his audience should retain: «It is not possible for an Italian to forget his Nation, unless this Italian is so degenerate to deserve the loss of his nationality as extreme punishment». ${ }^{71}$ This dream of affirmation of «Italianness» abroad had a fundamental redemptive and self-reflective function: moving from the idea of «motherland» to the «nation» and threatening the loss of «nationality», Bassi reveals the fascist regime's hegemonic design of highlighting, primarily at the domestic level, the dream of the strong nation on which Mussolini's Imperial project was founded. The problem here is that the fictitious

${ }^{68}$ Nicola Lablanca and Giuseppe Messerotti Benvenuti, Un Italiano nella Cina dei Boxer: Lettere (1900-1901), Modena: Associazione G. Panini, 2000. The 400 photographs have been collected and stored at the «Raccolte Fotografiche Modenesi Giuseppe Panini -Collezione Marzio Govoni», Modena, Italy.

${ }^{69}$ See footnote 69. V. Fileti, La concessione, pp8-9.

Ugo Bassi, pp.20-21.

${ }^{70}$ Ugo Bassi, p.29.

${ }^{71}$ Ugo Bassi. 
construction of this defiantly optimistic macro-story of benign colonialism may be unable to repulse an all-to-beguiling narrative of repeated systemic failure, which unmasks the continuous, desperate attempt to catch up with the other imperialist nations.

A demonstration of the instrumental self-reflexivity of this benign colonialism is offered by the renaming of the streets. The matrix of names like Fiume, or Trento Trieste, for example, belongs to the rhetoric of Italian nationalistic ideology, since they are explicit references to the process of Italian unification (officialised in 1871), and emphase the reclaiming of the north eastern «just borders» (namely Trento, Trieste, and the Dalmatian coast with the city of Fiume). This was the motivation for the Italian interventionism in the First World War: in order for the country to become complete is was necessary to regain those bordering areas.

Within the faraway, idealized borders of the concession, the Italian nationalistic tropes were exported and reinvented, assuming a powerful symbolic value for the Italian audience at home. This is particularly evident from the following representation offered by engineer Borgnino:

«Vittorio Emanuele III Boulevard, 24 metres wide, was the main arterial street of our concession. This boulevard, crossed through by a tram line managed by a local company, absorbs all the traffic from the Chinese city to the Tianjin east railway station and the other concessions. Obviously, the public buildings should have been erected on this Boulevard. $\gg^{72}$

\section{The Italian Concession in the Chinese Sources}

The image of Italian benign colonialism stands in sharp contrast with the representation offered by the Chinese sources, at least until the end of the 1980s. The 1926 source Tianjin zujie ji tequ is extremely precise about the nature, the origin and the organisation of the concession. ${ }^{73}$ In general, in the Chinese historical sources, the Italian concession does not appear to be considered of extreme significance in the studies dedicated to foreign concessions in Tianjin. Most of the time it is mainly remembered for the architectural style, creating another sort of self- orientalism.

In the «Short History of Tianjin (Tianjin Jianshi)» three lines are dedicated to the whole history of the Chinese-Italian relations:

${ }^{72}$ R. Borgnino, «La 'Concessione'», p.363.

${ }^{73}$ Nankai Daxue zhengzhi xuehui, ed., Tianjin zujie ji tequ, pp.6-7 
«On the twentieth year of the reign of Guangxu (1900), Italy with the status of 'occupying country (zhanlingguo)' invoked the Italian-Chinese 'Beijing treaty' signed by Tongzhi during his fifth year of reign (1866), requested to enjoy the 'most favoured nation status', and established a concession in Tianjin. During the twenty-eight year of the reign of Guangxu (1901), the Italian official ambassador in China, Gallina, signed with the Director of the Chinese Maritime Customs, Tang Shaoyi, 'The Agreement Containing the Rules and Regulations of the Italian Concession in Tianjin' with assigned an area on the northern bank of the Haihe as Italian concession. The total surface was $771 \mathrm{mu}$. $\gg)^{74}$

One of the few significant and detailed articles that I have been able to find on the Italian concession begins with the analysis of the origins of the concession. In the first paragraph, the author Jihua immediately sets the tone of a very different kind of imagined community when compared with the Italian sources. Jihua recognises the Italian role as part of the allied forces and military character of the Italian participation: «In the year 1900 the eight-nation alliance army invaded China, captured Tianjin and Beijing. Italy sent an army to take part into this war of aggression, and the troops were stationed in Tianjin». ${ }^{75}$ The terms used are all militarily connotated and unanimously convey the idea of aggression and invasion. Moreover, the acquisition of the Italian concession is seen in line with the general trend of the other nations. The author depicts Italy, Belgium and Austria as latecomers in the scramble for concessions, emphasising that they basically imitated the shamefully successful example of the other nations (England, France, United States, Germany and Japan), using military alliances and aggressive warfare (the Chinese expression used here is jiqixiaoyou).

After a description of the origin of the concession and its administrative structure, the author mentions a series of important Chinese individuals - like Tianjin Mayors Zhang Tinge, Cheng Ke, and Zhou Longguang for example- who lived in the Italian concession after the creation of the Republic, and in particular between 1917-1933. ${ }^{76}$ But even these top Chinese officials do not find similar attention in the Italian sources. The article continues, creating a peculiar story of gambling, drug production and use as being common phenomena in the Italian concession. The

${ }^{74}$ Tianjin Shehui Kexueyuan Lishi Yanjiusuo, Tianjin Jianshi, Tianjin: Renmin Chiubashe, 1987, p. 208. Another reference to Italy in this book is on pages 203-205 when the authors describe the operations of the eight-allied army. The book opens with a calligraphic dedication by Deng Xiaoping: «To educate the people of Tianjin».

${ }_{75}^{7}$ «izujie», p. 134. The Chinese transliteration for «Italy» is still using the character «yi» for justice or righteousness, as opposed to the character «yi» for meaning or intention which is in use today.

${ }^{76}$ Yizujie, pp. 137-138. 
author also reports a case of rampant speculation, which would have characterised the entrepreneurs operating in the Italian concession, to the extent of creating, in the late thirties, a sort of "paradise on earth (leyuan)» for illegal trafficking and profiteering. The last part of the article delves into the deepening of the Christian influence in the concession, which was perceived as a sign of imperialist penetration.

This representation stands in sharp contrast with the positive image which has appeared in the Chinese sources in the last few years, in line with the attempt to repackage the colonial past and sell it as the beginning of the internationalization of Tianjin. The "Year of Italy in China» was celebrated in 2006, and Tianjin tourist maps pointed at the «Italian style scenic streets» (Yishi fengqingjie), while the taxi drivers seemed to know where the former Italian concession was located. Not surprisingly since a major rebuilding process is underway to create a commercial area with a new flavour of «Italianness». It is striking to notice the cycles of destruction-reconstruction where the old buildings are merging with the new ones, creating a paradoxical effect where reality and virtual images, past and present, are so intertwined as to become undistinguishable. But the locale still carries the

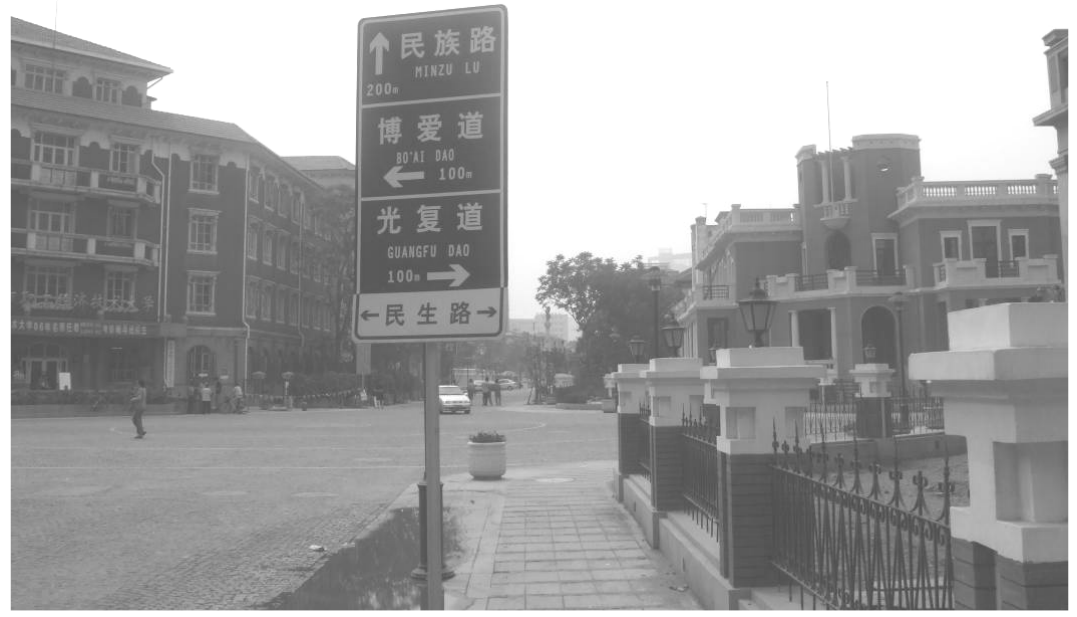

Figures 8. Photograph taken on 24 June 2006 in Minshenglu in the ex-Italian concession. 


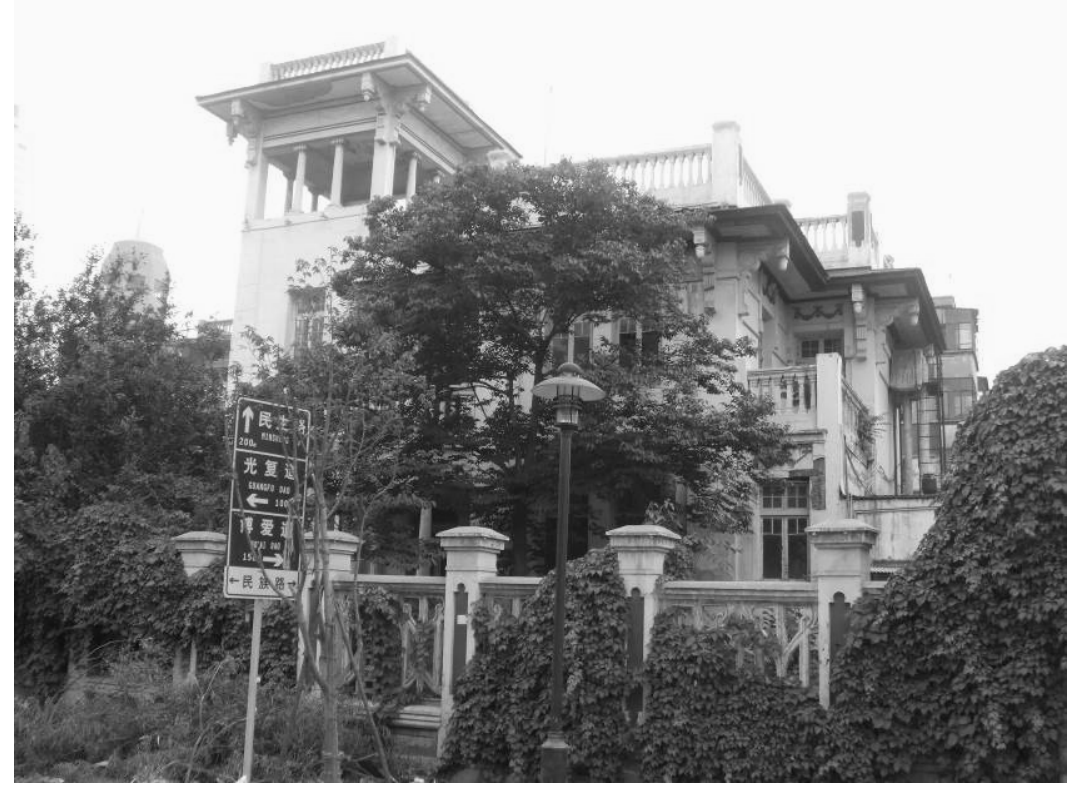

Figures 9. Photograph taken on 24 June 2006 in Minzulu in the ex-Italian concession.

burden of the colonial and post-colonial historical legacy, since this small area is inscribed in a perimeter delimitated by the streets carrying the names of the «three principles of the people», coined in 1924 by the «Father of the Republic» Sun Yatsen: Minzu (Nationalism, by which Sun meant freedom from imperialist domination), Minzhu (Democracy, which for Sun represented a Western constitutional government), Minsheng (People's welfare, or livelihood, or «Government for the People»)..$^{77}$

77 In the case of China, political life should have been ideally combined two «powers»: the power of politics (zhengquyan) with the power of governance (zhiquan).

Minsheng can also be translated as socialism, although the government of Chiang Kai-Shek shied away from translating it as such. The concept may be understood as social welfare since Sun divided livelihood into four areas: food, clothing, housing, and transportation. According to Sun, an ideal (Chinese) government should fulfill these duties for its people. See Sun Yat-Sen, San Min Chu I: The Three Principles of the People, trans. Frank W. Price, Shanghai, China: China Committee, Institute of Pacific Relations, 1927, pp.189-92, pp201-2, pp.210-11, pp.262-63, p.273, and p.278 


\section{Conclusion}

The Treaty of Paris signed on 10 February 1947 deprived Italy of its colonies and also of the Tianjin concession..$^{78}$ In the case of Tianjin, this final act was merely a formality. Four years before, at the beginning of 1943, Italy had already agreed with its then ally Japan to renounce exercising any power on Chinese citizens and transferring the responsibility to the Nanjing Government.

Scholars of African colonialism have analysed and emphasised how the Italian ruling class «refused to initiate a serious, organic, broad, definitive debate on the phenomenon of colonialism».79 This essay on the only case of Italian colonialism in Asia aims to contribute to this intellectual debate. This endeavour requires a reconceptualisation of history which de-mystifies its fictive and multidimensional character. The broader scope of my work is strictly speaking methodological: how do we engage with colonial and postcolonial forms of «knowledge» concerning the microcosm of the Italian concession? What can we learn from the investigation of this «reality», which might also be valid for other colonial representations and practices? My intention is to look through the conscious or unconscious implementation of explicit or implicit schemes of perception, which tend to affirm the sovereignty of the colonial subject. I seek to unmask the narrative mechanisms which show an all-too-beguiling appreciation of the Italian intervention in Tianjin and capitalise on the absolute depreciation of the pre-existent situation.

The African historian Achille Mbembe has poignantly argued for the necessity of analysing the colonial experience in a more lucid way, and has recently launched a proposal that I believe might also be useful for the study of the Italian (and not only) experience in China. ${ }^{80}$ Mbembe investigates the attempt of African post-colonial nations to liberate themselves from the symbols of European domination, imagining other ways of organizing the public space. The process of renaming/reclaiming their countries has implied a symbolic re-appropriation of a previously expropriated geopolitical universe and historical capital: by rechristening the cities, some nations have expressed their desire to reclaim the urban landscape. Mbembe argues that:

\footnotetext{
${ }^{78}$ Section 5 «Special Interests in China», articles 24, 25, 26.

${ }^{79}$ Patrizia Palumbo, ed., A Place in the Sun: Africa in Italian Colonial Culture from Post-Unification to the Present, Berkeley: University of California Press, p.18.

${ }^{80}$ Le Messager di Douala, in Camerun, 29/03/2006, available on line: «Pour une sépulture symbolique au colonialisme»,

http://www.africultures.com/index.asp?menu=revue_affiche_article\&no=4365\&section=rebonds, accessed 2 May 2006.
} 
«The memory of colonisation has not always been a happy memory. But going against a tradition rooted in the African consciousness of victimisation, in the colonial work there was not only destruction. Colonisation itself was not only an infernal machinery. It was crossed everywhere by escape lines. The colonial regime consecrated most of its energies both in the attempt of controlling those escapes, and in their use as a constitutive dimension, even decisive, of its selfregulation. It is not possible to understand how the colonial system came into being, and how it disarticulated itself, without understanding these escapes as the form itself assumed by the conflict. $»^{81}$

Based on this argument, Mbembe launches the following proposal:

«I hope that in every African country there will be soon a detailed collection of statues and colonial monuments. They should be gathered in one single park, which will function both as a museum for the future generations and as symbolic burial of colonialism on the continent. After the completion of this ritual, it will not be possible for us to use ever again the colonisation as a pretext for our contemporary disgraces. And since we are talking about this, let's decide that we will not erect any statue to anybody anymore. On the contrary, let's build libraries, theatres, cultural venues: all those things that can nurture cultural creativity for the future. $»^{82}$

From the point of view of the reorganisation of colonial and postcolonial cityscape, the concessions' area in Tianjin could offer a clearly identifiable base to start from and further implement Mbembe's cultural project. This possibility, as an alternative to a whole-scale marketization of the area, is the first tentative direction that I would like to suggest in my conclusions.

Secondly, this article is also intended as an attempt to create an imaginary dialogue between the sources and, hopefully, open new ways of discourse between Western and Chinese historians. The process of unmasking the different layers of representation has led to the appearance of dialectically contesting images of the Italian concession. What has emerged in fact, is not an illusory objective reconstruction of a unilateral identity of the Italian concession, but more likely two (or more) possibilities of - often competing and contentious - stories. The dialectic between these stories stands as a sign of resistance, and perhaps even analytical subversion, aimed at breaking those unifying and homogenizing tendencies which pretend to make the other invisible, instead of accepting its intrinsic presence within ourselves.

${ }^{81}$ Le Messager di Douala.

${ }^{82}$ Le Messager di Douala. 
The third conclusion that I draw from my research, is that the images of the concession in the Italian sources reveal a sort of historical nemesis, both against the late and unsuccessful start of the Italo-Chinese relations, and, probably even more, towards the other colonial powers present in China at the time. The unilaterally extremely positive representations of the transformation of the territory of the Italian concession, with the consequent erasure of the Chinese village and the superimposition of an hyper-Italian identity, can be interpreted within the conceptual framework of the longing for recovering prestige and legitimacy for the international recognition of Italy as a unified and modern state with equal dignity as the other powers. The expression of colonial agency at the turn of the XX century is the sine qua non for the affirmation of the possibility of being recognised as a «modern nation». Italian sources reveal that the acquisition of the concession is not important so much as it was granted by the Chinese Government, but more so because of its specular value, as it was meant to demonstrate that Italy was also able to assert itself as a colonial power.

At the same time, and somehow subjectively exceeding this level of national recognition, the sources analysed demonstrate the effort to portray Italian colonialism as a benign colonialism, as if Italian actions in Tianjin were evidence of a benefactor's willingness to assist the local community. This fictitious narrative reached its climax during the fascist period when Italian sources provided legendary statements, claiming that Italians were so popular and welcome in China that an esteemed (but not identified) Chinese literati would have even said, «Oh! If our compatriots had trusted Marco Polo! ${ }^{83}$ This ambiguous statement was taken at face value, as demonstrative of the deep regret for the «late» Italian intervention in China.

This image of Italy as benefactor resonates with the intention to affirm «Italianness», which is packaged and exported to the imagined micro-community of the concession, to legitimize the collective identity of the newly formed unified Italian nation both domestically and internationally. With the advent of Mussolini's regime, one witnesses the apotheosis of the claimed superiority of the Italian spirit. The Italian concession was then depicted in the typical light of Orientalist selfreflexivity, but exacerbated by the overtones of fascist propaganda. This parable reveals the paradox of a projected image, which had grown increasingly apart from the problematic contingencies of the internal situation:

${ }^{83}$ See for example: M. Catalano, «La nostra concessione di Tien Tsin», in Le Vie d'Italia e del Mondo, May 1936, reported in Cesare Cesari, La Concessione Italiana di Tien-Tsin, Roma: Istituto Coloniale Fascista, 1937, N. 4, XV (12th of the series), p.23. 
«(This) small territorial entity is an eye in the faraway Orient, on which should converge both the attention of all the Italians, and the appreciative thanks for those who held high the name of the homeland. No matter what events unfold in the Chinese social or political compages, the Tien Tsin concession will remain, as Il Duce (Mussolini) defined it, an extremely advanced sentry of Italian civilization. ${ }^{84}$

${ }^{84}$ C. Cesari, «La Concessione », p.23. 